\title{
Research Article \\ Research on the Impact of 3D Printing on the International Supply Chain
}

\author{
Zhen Chen ${ }^{1,2}$ \\ ${ }^{1}$ Business School, Lingnan Normal University, Zhanjiang 524048, China \\ ${ }^{2}$ South China Sea Silk Road Collaborative Innovation Centre, Lingnan Normal University, Zhanjiang 524048, China
}

Correspondence should be addressed to Zhen Chen; 1892936@qq.com

Received 5 December 2015; Revised 13 April 2016; Accepted 17 April 2016

Academic Editor: Giorgio Pia

Copyright (C) 2016 Zhen Chen. This is an open access article distributed under the Creative Commons Attribution License, which permits unrestricted use, distribution, and reproduction in any medium, provided the original work is properly cited.

\begin{abstract}
In recent years 3D printing technology is developing rapidly. In the foreseeable future, when 3D printing is widely used, the world's industrial structure will be greatly changed. Based on the actual data, this paper constructs an international supply chain model using system dynamics method. And it simulates the reconstruction trend of the supply chain after 3D printing application. The conclusion shows that the universal application of 3D printing will lead to the worldwide transport volume shrinking dramatically. The manufacturing activities will gradually outflow to the countries which are closer to the final customers. The relevant countries should carry out feasible measures to face this opportunity and challenge. The measures include the reform of logistics facilities, the logistics cooperation with the origin of 3D printing materials, and the matched transportation of $3 \mathrm{D}$ printing materials and traditional processing ones.
\end{abstract}

\section{Introduction}

$3 \mathrm{D}$ printing is a rapid prototyping mode without mold making. It is also known as the material additive manufacturing. Based on the 3D digital model file, it constructs the object through printing the materials layer by layer. This technology needs the raw material much less than the traditional one which uses rough pruning forming. Through changing the model's configuration, it could respond to the consumers' demand more flexibly. The academia and the industry think it will subvert the production rules set from the first industrial revolution era. 3D printing and other modes of digital production will promote the realization of the third industrial revolution together. The social, economic, and technical 3D printing revolution is on the way. The entrepreneurs, policy makers, and society at large will encounter unforeseen opportunities and challenges [1].

In recent years $3 \mathrm{D}$ printing technology continued developing, especially the breakthroughs in the material application. More than one hundred of raw materials can be used for 3D printing. They include thermoplastic plastics, metal, nylon, acrylic, plaster, ceramic, and edible material. The expansion of the material type will promote the application of this technology in more productive areas. Nowadays this technology could be used to produce spare parts, singular parts, bioconstructs, micromachines, electronics, and even jewelry [2-9].

On the other hand, the relevant academic research is gradually increasing. But the existing literature concerns the improvement of this technology. The study of 3D printing impact on the society is lacking and more concentrated in the business reports. The academic quantitative analysis is not enough.

How does 3D printing change the traditional industrial layout and production mode? Petrick and Simpson thought that $3 \mathrm{D}$ printing would disrupt the conventional manufacturing and create new rules of competition [10]. Zeleny proposed that this technology could eliminate much of the traditional labor and make many complex products, which allowed the customization of products for consumers. That may cause the relocalization of manufacturing [11]. Mellor et al. thought that when mass production was transferred to the developing countries, European and US companies had to switch to the more innovative, customized, and sustainable products with high added value. Combined with the $3 \mathrm{D}$ printing technology, they proposed a framework, to guide the project 
managers to produce high value products and bring new business opportunities [12]. Kurfess et al. thought that when the customer are involved in the production process, the application of 3D printing would bring the problem of intellectual property. After solving it, this technology would bring large scale of open innovation $[13,14]$.

After the application of 3D printing, with the customer's requirement of self-customizing, would the manufacturing industry transfer back to the developed countries or not? Is the future industry layout global or local? Thiesse et al. proposed that the existing manufactures may react by pricing reduction or product enhancements, to increase the appeal of their offering. On the other hand, the centralized conventional manufacturing system was strong and difficult to break up. The reconstruction of global supply chain may not happen in a short time [15]. Weller et al. thought that this technology would be popular when it met four market principles, versatile manufacturing machine, customization and flexibility for free, complexity for free, and reduction of assembly work [16].

But the wide application of $3 \mathrm{D}$ printing technology does not mean the disappearance of traditional one. In the actual manufacturing process, the new and the traditional technology should be combined together. Zhu et al. reviewed the hybrid processes reported over the past twenty years and proposed the possible future processing pattern. That would combine the $3 \mathrm{D}$ printing and other conventional modes, including subtractive, transformative, joining, and dividing technology [17]. Monostori et al. thought that when new technologies were applied, the conventional rigid, centralized, and hierarchical producing way would change. He suggested that the future of manufacturing and logistics system should be dynamic, open, and reconfigurable [18]. Khajavi et al. reported a case of spare parts supply chain in the real world. Then they discussed the hybrid approach through direct digital and tool-based manufacturing, which means the combination of $3 \mathrm{D}$ printing and traditional measures $[19,20]$.

How does the logistics industry deal with the situation after the supply chain reconstruction? There are many business predictions. Transport Intelligence website released a report "The Implication of 3D Printing for the Global Logistics Industry," mentioning that 3D printing technology will bring about the production activities in Asia to return to North America and Europe [21]. It will lead to the decline in the shipping and air cargo volume. The transportation cost saved is incredible. Jin et al. proposed that, in addition to the global freight volume reduction, the level of inventory will also decline. This is because $3 \mathrm{D}$ printing can improve the efficiency of the production as needed. Lower transportation and warehousing business will force logistics enterprises to transform. That includes merging 3D printing into logistics activities, focusing on $3 \mathrm{D}$ printing material logistics and developing the supply-chain control tower business [22]. Dawes et al. took metal powder as an example and predicted that in the future the $3 \mathrm{D}$ printing materials would come from three groups, 3D printer equipment suppliers, third party suppliers, and directly the material makers. When designing the supply chain, these groups' unique advantages and disadvantages should be concerned [23]. Barz et al. used a facility location model to quantify the potential impact of 3D printing. They proposed that the production process could be set into two stages. The first was from source node to production node, and the second was from production node to customer node. After examining the data from 308 instances, they found that $3 \mathrm{D}$ printing technology could reduce the overall transportation costs of a supply network. But the share of the cost on the second stage increased. The production nodes and customer nodes should be spaced more closely to improve their cost effectiveness [24].

The literature above mainly discussed that manufacturing reflow and supply chain transformation lead to the reduction of global freight volume. That would affect the logistics industry. But the international quantitative analysis was lacking and could not be used to measure the magnitude of the transport reduction and variation trend in the worldwide range. Even in the geographical distribution research, their focuses were usually on the freight volume but not on the time consumption. What opportunities and challenges will the freight volume and time in the overall reduction bring to the countries, respectively? In the current industrial pattern, many Asian countries are main manufacturers. Europe and the United States only focus on R\&D and sales. Some other countries are raw material suppliers. When the application of $3 \mathrm{D}$ printing leads to the so-called "manufacturing reflux" hypothesis, will the freight volume of Asian countries decline? Will the freight volume of Europe and the United States rise? What about the change of those raw-material export countries?

This paper intends to study the spatial and temporal variation of the supply chain in the worldwide range. Based on the existing world industrial division of labor, this research establishes a system dynamics model. In the model, the raw materials production, processing, assembly, and final sale and their transportation among the several nodes constitute a transnational supply chain. Through the simulation of the model, this paper strives for breakthrough in quantitative research. In addition, the model considers the combination of traditional processing technology and 3D printing technology, to discuss whether the latter could completely replace the former. Then we put forward the countermeasures. The results of this paper can make the research in this field more specific and operational.

\section{Model Construction}

At present, 3D printing has not been widely applied in the manufacturing field. Its impact on supply chain is limited. But this technology has gained the attention of the world's main industrial powers. It is on the way of high-speed development. In the foreseeable future, when the $3 \mathrm{D}$ printing and other digital technologies change the traditional processing modes, the world's industrial geographical distribution will undergo a dramatic change [5].

This paper aims at analyzing the influence of $3 \mathrm{D}$ printing on the international supply chain logistics. Due to the lack of practice data, the model is based on the simplified data of existing normal cases. Then it is simulated in different circumstances. Through quantitative analysis and comparison of the simulation results, we can preliminarily predict this 
TABLE 1: Variable symbol of international supply chain.

\begin{tabular}{lccccc}
\hline Symbol & Meaning of variables & Symbol & Meaning of variables & Symbol & Meaning of variables \\
\hline$\alpha$ & Raw material $\alpha$ & $\beta$ & Raw material $\beta$ & $\gamma$ & Semiproduct $\gamma$ processed by $\alpha$ \\
$\delta$ & Semiproduct $\delta$ processed by $\beta$ & $\varepsilon$ & Finished product $\varepsilon$ & OA & The origin of $\alpha$ in A \\
OB & The origin of $\beta$ in B & PA & The port in A & PB & The port in B \\
PC & The port in C & PD & The port in D & PPC $\alpha$ & The processing plant of $\alpha$ in C \\
PPC $\beta$ & The processing plant of $\beta$ in C & APC & The assembly plant in C & DCA & The distribution center in A \\
DCB & The distribution center in B & DCC & The distribution center in C & DCD & The distribution center in D \\
\hline
\end{tabular}

technology's impact on the whole supply chain. This could be a reasonable suggestion for related industries. They could face the opportunity of 3D printing and make layout in advance.

2.1. Construction Ideas. A basic supply chain model is constructed based on the system dynamics. The data is from the existing normal cases and has been simplified. Different from Barz's research [24], here the production process is set into three stages, firstly from source node to processing node, secondly from processing node to assembling node, and finally from assembling node to customer node. The reason is that the components' processing activities and assembly activities are usually in the different regions, according to the international manufacturing division nowadays. So the model building ideas are as follows.

The goods are made from two kinds of raw materials, $\alpha$ and $\beta$. Raw material $\alpha$ is from country $\mathrm{A}$, and raw material $\beta$ is from country $\mathrm{B}$. These two materials are transported by train from their origins to the port and then to country $\mathrm{C}$ by sea. In country $\mathrm{C}$, raw materials $\alpha$ and $\beta$ are processed into semiproducts $\gamma$ and $\delta$, respectively, in different processing plants. In the procedure of processing, the material loss is very large. Then the semiproducts $\gamma$ and $\delta$ are assembled into the final product $\varepsilon$. The material loss is neglected in the assembling.

$20 \%$ of the final products are sold in country C, and the remaining is shipped out and sold to countries $\mathrm{A}, \mathrm{B}$, and $\mathrm{D}$. The sales ratio is A $10 \%, \mathrm{~B} 10 \%$, and $\mathrm{D} 60 \%$, respectively. To simplify the model construction, each country only sets a port for the cargo import and export.

The model is established by the VENSIM PLE software. The significance of the variable is as Table 1 .

The existing international supply chain mode is called Scheme 1, and its system dynamics model is shown in Figure 1. The model starts from $\mathrm{OA}$ and $\mathrm{OB}$. The raw materials are transported to country $\mathrm{C}$, then get processed and assembled, and finally are made into the product $\varepsilon$. Some of $\varepsilon$ are sold in $C$, and the other ones are sold in $A, B$, and C. So the model ends at DCA, DCB, DCC, and DCD, to meet the needs of local consumers.

Then a numerical simulation of the model is conducted. The data is based on the actual commodity manufacturing process and carried out a certain simplification. The simulation settings are as follows:

(1) The simulation range is from 1 to 90 . The step size is 1 day. The logistics status and varying trend of raw materials, semiproducts, and finished products in the supply chain are investigated.
(2) In the model, $\alpha$ and $\beta$ are set for bulk transportation. This is because raw material is of large cargo volume and low value, so in the industry they are generally chosen to be transported in bulk. In terms of transportation mode, the cargo goes by railway from the origin to the port and then from the port to the processing plant. The frequency is one train in two days. When the cargo goes from one port to another port, ocean shipping is chosen. Its frequency is one ship in five days. The PULSE TRAIN function is used to achieve this setting.

(3) In the model, $\gamma$ and $\delta$ are set for container transportation. This is because after being processed and purified semiproduct is of higher value and lower volume. So in the industry it is generally chosen to be transported in container. In terms of transportation mode, the cargo goes by railway from the processing plant to assembly plant. The frequency is one train in one day.

(4) In the model, $\varepsilon$ is set for container transportation. Final product is generally of low volume and multiple batches. So it is fit for container by truck. That would be more flexible than by railway. In terms of transportation mode, the cargo goes by road from the assembly plant to the distribution center or the port. The frequency is one truck in one day. When the cargo goes from one port to another port, ocean shipping is chosen. Its frequency is one ship in three days, because the container ship's schedule is more frequent than the bulk ship. The PULSE TRAIN function is used to achieve this setting.

(5) In the setting, the supply chain is not allowed to be out of stock. That means the real-time inventory in any part of the model cannot be less than zero. When the cargo reaches anyone's node, it must be in situ for reorganizing at least one day before being transported to the next location. The STEP function is used to achieve this setting. In order to ensure the supply chain in the shortest length and lowest inventory, when the cargo arrives at any node, it must be transported as soon as possible. Staying at a same place for a long time is not allowed [25].

(6) The output of $\alpha$ is 600 tons per day, and its processing loss rate is $2 / 3$. The output of $\beta$ is 400 tons per day, and its processing loss rate is $1 / 4$. The output of $\varepsilon$ is 500 tons per day. Producing every 1 ton of $\varepsilon$ needs $\gamma 0.4$ tons and $\delta 0.6$ tons. The manufacturing of $\varepsilon$ is 


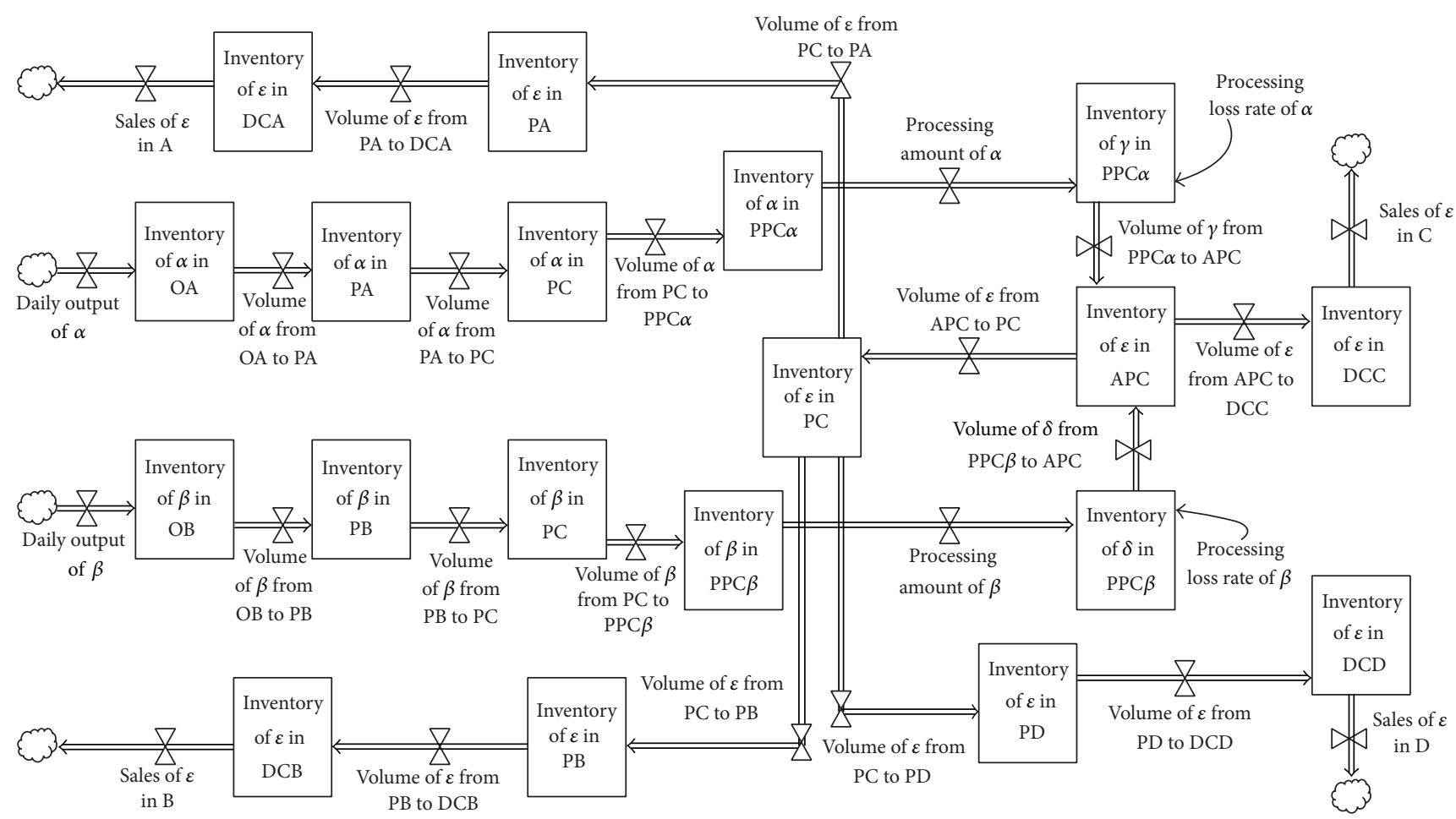

Figure 1: Flow diagram of Scheme 1.

mainly the assembly of $\gamma$ and $\delta$. Its processing loss rate is ignored. That means 1 ton of $\varepsilon$ needs $\alpha 1.2$ tons and $\beta 0.8$ tons.

(7) The sales volume of $\varepsilon$ is set at about 50 tons in A, 50 tons in B, 100 tons in $\mathrm{C}$, and 300 tons in D. So the supply and marketing are in coordination. A produces $\alpha 600$ tons, B produces $\beta 400$ tons, and $\mathrm{C}$ produces $\varepsilon$ 500 tons, respectively, per day. And the cargo will be sold out in the four countries.

(8) The transit time of the cargo is set based on the actual geographic data and the selected transport mode, as shown in Table 2.

2.2. Simulation Results. According to the settings in Table 2, the model runs the simulation of the international supply chain in 90 days. The objective of the analysis is to determine the country's domestic and international logistics situation. It needs the total freight volume of land and the port throughput in different countries. Then we classify the statistics according to different countries. The results are shown in Table 3.

The study of the entire supply chain logistics also needs the transportation cost during the simulation. The freight rates of various modes according to the actual data are set in Table 4, where the currency is unified use of USD (US dollar) based on the international trade practices.

According to Table 4, the calculation results are shown in Table 5.

\section{Model Reconstruction}

3D printing technology is developing. In the future it will get applied in more and more fields. The traditional international supply chain will be reconstructed to adapt to its development. This paper assumes that $\gamma$ which is made of $\alpha$ will be produced through $3 \mathrm{D}$ printing in the future. But due to technical limitations $\delta$ which is made of $\beta$ cannot be produced through this technology. It remains the traditional processing method. The paper also assumes that the demand of $\varepsilon$ does not change after the supply chain reconstruction. It is still 50 tons/day in A, 50 tons/day in B, 100 tons/day in C, and 300 tons/day in D. And it will have the following trends.

3.1. The First Possibility. Using 3D printing technology to process $\alpha$, the primary supply chain may have the following three changes.

3.1.1. The Change of Material Loss. In the processing of the semiproducts, the material loss will be very low when using 3D printing. This is because this technology of additive manufacturing is not required to remove or cut materials. In Scheme 1 , when the demand of $\varepsilon$ is 500 tons/day, the output of $\alpha$ is 600 tons/day and $\beta$ is 400 tons/day, respectively. Here the model has a new setting that, after the application of $3 \mathrm{D}$ printing, the processing loss rate of $\alpha$ changes from $2 / 3$ to $1 / 2$, and the rate of $\beta$ does not change. To meet the demand of $\varepsilon$, the necessary production of $\alpha$ reduces to only 400 
TABLE 2: Setting of parameters in Scheme 1.

\begin{tabular}{|c|c|c|c|c|}
\hline Country A & $\begin{array}{c}\text { Distance between } \\
\text { OA and PA }\end{array}$ & $\begin{array}{c}\text { Distance between } \\
\text { PA and DCA }\end{array}$ & & \\
\hline & 4 days & 2 days & & \\
\hline \multirow[t]{2}{*}{ Country B } & $\begin{array}{c}\text { Distance between } \\
\mathrm{OB} \text { and } \mathrm{PB}\end{array}$ & $\begin{array}{c}\text { Distance between } \\
\text { PB and DCB }\end{array}$ & & \\
\hline & 4 days & 2 days & & \\
\hline \multirow[t]{6}{*}{ Country C } & $\begin{array}{c}\text { Distance between } \\
\text { PC and PPC } \alpha\end{array}$ & $\begin{array}{c}\text { Distance between } \\
\text { PC and PPC } \beta\end{array}$ & $\begin{array}{l}\text { Distance between } \\
\text { PPC } \alpha \text { and APC }\end{array}$ & $\begin{array}{c}\text { Distance between } \\
\text { PPC } \beta \text { and APC }\end{array}$ \\
\hline & 1 day & 2 days & 1 day & 1 day \\
\hline & $\begin{array}{l}\text { Processing time in } \\
\text { PPC } \alpha\end{array}$ & $\begin{array}{c}\text { Processing time in } \\
\text { PPC } \beta\end{array}$ & $\begin{array}{l}\text { Assembling time in } \\
\text { APC }\end{array}$ & \\
\hline & 5 days & 3 days & 2 days & \\
\hline & $\begin{array}{c}\text { Distance between } \\
\text { DCC and APC }\end{array}$ & $\begin{array}{c}\text { Distance between } \\
\text { PC and APC }\end{array}$ & & \\
\hline & 2 days & 1 day & & \\
\hline \multirow[t]{2}{*}{ Country D } & $\begin{array}{c}\text { Distance between } \\
\text { PD and DCD }\end{array}$ & & & \\
\hline & 2 days & & & \\
\hline \multirow[t]{2}{*}{$\begin{array}{l}\text { Distance between } \\
\text { the ports }\end{array}$} & $\begin{array}{c}\text { Distance between } \\
\text { PA and PC } \\
\end{array}$ & $\begin{array}{c}\text { Distance between } \\
\text { PB and PC } \\
\end{array}$ & $\begin{array}{c}\text { Distance between PC } \\
\text { and PD }\end{array}$ & \\
\hline & 15 days & 18 days & 23 days & \\
\hline
\end{tabular}

TABLE 3: Simulation results of freight volume and period in Scheme 1.

\begin{tabular}{|c|c|c|c|}
\hline Country A & Land freight in $\mathrm{A}$ & Port throughput in $\mathrm{A}$ & Starting sales time of $\varepsilon$ in $\mathrm{A}$ \\
\hline & 55700 tons & 52800 tons & The 59th day \\
\hline \multirow[t]{2}{*}{ Country B } & Land freight in B & Port throughput in $\mathrm{B}$ & Starting sales time of $\varepsilon$ in B \\
\hline & 37550 tons & 35650 tons & The 62nd day \\
\hline \multirow[t]{2}{*}{ Country C } & Land freight in $\mathrm{C}$ & Port throughput in $\mathrm{C}$ & Starting sales time of $\varepsilon$ in $C$ \\
\hline & 120100 tons & 88400 tons & The 40th day \\
\hline \multirow[t]{2}{*}{ Country D } & Land freight in $\mathrm{D}$ & Port throughput in $\mathrm{D}$ & Starting sales time of $\varepsilon$ in $\mathrm{D}$ \\
\hline & 7800 tons & 8100 tons & The 67 th day \\
\hline
\end{tabular}

TABLE 4: Freight rates of various transportation modes.

\begin{tabular}{lccccc}
\hline Transport mode & $\begin{array}{c}\text { Railway bulk } \\
\text { cargo }\end{array}$ & $\begin{array}{c}\text { Railway } \\
\text { container cargo }\end{array}$ & $\begin{array}{c}\text { Marine bulk } \\
\text { cargo }\end{array}$ & $\begin{array}{c}\text { Marine } \\
\text { container cargo }\end{array}$ & $\begin{array}{c}\text { Road container } \\
\text { cargo }\end{array}$ \\
\hline Freight rate & USD 3/ton & USD 6/ton & USD 2/ton & USD 4/ton & USD 15/ton \\
\hline
\end{tabular}

TABLE 5: Simulation results of freight cost in Scheme 1.

\begin{tabular}{|c|c|c|c|c|}
\hline The cost of land & In the territory of $\mathrm{A}$ & In the territory of $\mathrm{B}$ & In the territory of $\mathrm{C}$ & In the territory of $\mathrm{D}$ \\
\hline & USD 187500 & USD 131250 & USD 762300 & USD 117000 \\
\hline \multirow[t]{2}{*}{ The cost of ocean } & $\mathrm{A}-\mathrm{C}$ & $\mathrm{B}-\mathrm{C}$ & C-D & \\
\hline & USD 112200 & USD 78200 & USD 61200 & \\
\hline Total & USD 1449650 & & & \\
\hline
\end{tabular}

tons/day. Therefore, the overall demand of the raw materials will decline if the $3 \mathrm{D}$ printing technology is applied.

3.1.2. The Change of the Processing Site. Another change may be the processing site's shifting to the starting point of the chain. In the traditional processing mode, the semiproducts usually have fixed shape and structure. In the metal industry as an example, iron ore is processed into steel structure, rolled steel, or double-T steel. That would take time. So the processing site is often close to the final assembly location, 
to respond to the demand from the end. In Scheme $1, \alpha$ is processed to $\gamma$ in C.

However, after 3D printing's application, semiproduct $\gamma$ will be used instead of the printing materials with more flexible processing characteristic, such as metal powder and plastics wire. The processing site of $\alpha$ can be shifted to Country A. The symbol also changes from PPC $\alpha$ to PPA $\alpha$. And it should be built near OA. After the raw material $\alpha$ mining, transport it from OA to PPA $\alpha$ and process it into 3D printing materials $\gamma$. These materials will be transported to APC and printed in the required form and structure to manufacture $\varepsilon$. In Scheme 1, about 600 tons of $\alpha$ is needed to be transported per day in A. Now the amount reduces to only 200 tons of $\gamma$. It would greatly reduce the logistics volume and cost.

In the aspect of the $\beta$ processing, it is still carried out in C. That is because in the short term other production activities which are not related to $3 \mathrm{D}$ printing would remain unchanged. After $\beta$ is processed to $\delta$ in $\mathrm{C}$, it is shipped to $\mathrm{D}$ for assembly.

3.1.3. The Selection of $3 D$ Printing Site in the Supply Chain. The third change is the selection of 3D printing site. Where does the printing activity happen? In the existing literature, some scholars and industry forecast that most of the consumers can be convenient and flexible to print a variety of finished products in their home as long as buying a series of printing materials regularly. But it may not be achieved in the short term. First, the price of $3 \mathrm{D}$ printers varies greatly due to different printing materials. Printing costs for some materials are not affordable for ordinary consumers. And according to the current $3 \mathrm{D}$ printing process, different materials require different printers. For example, laser sintering printer is used for metal powder, stereo lithography is used for photosensitive resin, and so forth. But the existing goods are generally assembled from a variety of materials, from a small stapler to a big car. Ordinary consumers are not likely to spare more than one printer at home. Second, if the ordinary consumers want to print big items they need printers of larger volume. Printing different items needs the storage of a variety of printing materials. It will take up a lot of home space. Therefore, for most of the current products, even after the 3D printing technology widely used, their application fields are mainly in the factories. In the setting of this paper, the possibility of the consumers printing products at home is not considered.

But the final 3D printing site should be as close to the end of the chain as possible, so that it could more quickly respond to the changing demand of consumers. In this paper, the finished product's printing site is set in the assembly plant. The plant is the most close to the manufacturing end of supply chain. But which country is the assembly plant in? In Scheme 1, APC, only one assembly plant is in country C. After the application of the new technology, quite a number of the artificial assembly processes in the supply chain will be replaced by $3 \mathrm{D}$ printing. The global manufacturing mode will come to the end. The activities of finished product production will transfer to the place with huge volume of goods sold. That is so-called "manufacturing reflux" hypothesis which the existing literature proposed. Country D has the largest sales of the finished product $\varepsilon$. So this paper's setting adds one more assembly plant in D, which is called APD. APD only produces $\varepsilon$ for the consumers in D. And APC still produces $\varepsilon$ for countries $\mathrm{A}, \mathrm{B}$, and $\mathrm{C}$ because of constant trade practice.

Based on the above discussion and assumption, the supply chain model is changed from Figure 1 to Figure 2, which is called Scheme 2,

We add the setting of the new plants into the model. As the $3 \mathrm{D}$ printing technology is not widely used and the relevant data is lacking, Scheme 2 is as far as possible from maintaining the same as Scheme 1. The model parameters are set as shown in Table 6.

According to the settings in Table 6, the model runs the simulation of the international supply chain in 90 days. Then classifying the statistics according to different countries, the results are shown in Table 7.

The setting of freight rates of Scheme 2 is the same as Scheme 1. After calculation, the results of transportation cost are shown in Table 8.

3.2. The Second Possibility. In the setting, $\beta$ cannot be processed through $3 \mathrm{D}$ printing but traditional technology. In Scheme 2 the processing of $\beta$ is all conducted in C. When the manufacturing environment of the country $\mathrm{D}$ is attractive enough, some of the $\beta$ processing may be transferred to D. If the manufacture of semiproducts is more close to the final assembly plant, it will have a faster response and a better flexibility for the demand from the end of the chain. Therefore, in the second possibility of the supply chain reconstruction, one more processing plant of $\beta$ is built in $D$, which is called $\operatorname{PPD} \beta$. $\operatorname{PPD} \beta$ produces $\delta$ for $\varepsilon$ manufacture in D. $\varepsilon$ produced in $\mathrm{D}$ is sold only to $\mathrm{D}$. The other settings are the same as Scheme 2, and $\varepsilon$ produced in C are sold to A, B, and $\mathrm{C}$.

Based on the above discussion and assumption, the supply chain model is changed from Figure 2 to Figure 3, which is called Scheme 3.

Setting that the production parameters of $\beta$ are the same in $\mathrm{C}$ and $\mathrm{D}$, the model parameters of Scheme 3 are shown in Table 9.

According to the settings in Table 9, the model runs the simulation of the international supply chain in 90 days. Then classifying the statistics according to different countries, the results are shown in Table 10.

The setting of freight rates of Scheme 3 is the same as Scheme 1. After calculation, the results of transportation cost are shown in Table 11.

3.3. The Third Possibility. In the setting of Scheme 2, the processing site of 3D printing materials is located in $\mathrm{A}$. But the economic and technological conditions of the raw material origin countries are likely to be relatively backward in the actual international production environment. So the scheme that the raw material processed locally sometimes is not available, due to the lack of adequate capacity. Here we discuss another selection of the printing processing site, which is put in the main sales country. The production responds more quickly if it gets closer to the end of the chain. 


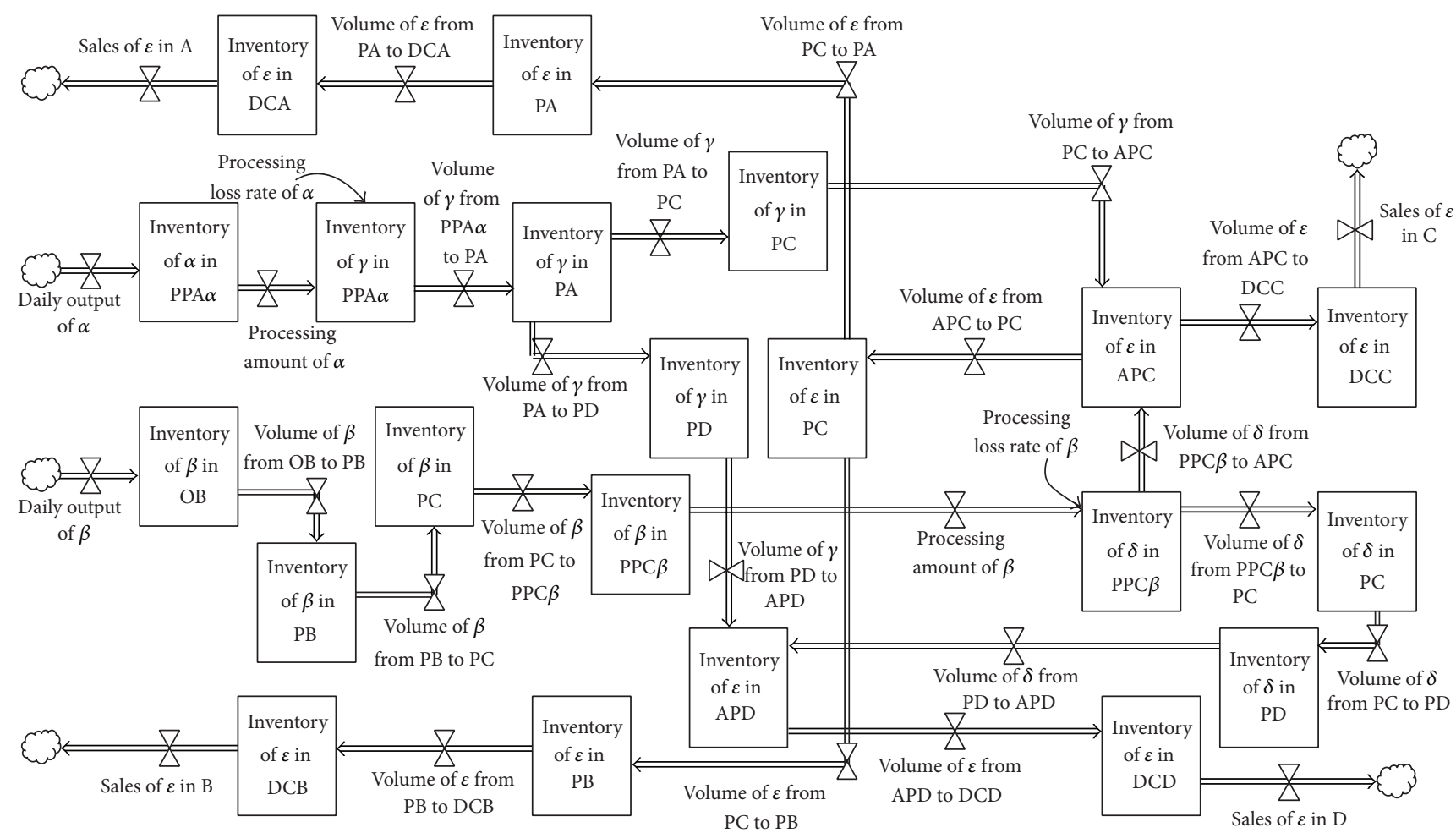

FIgURE 2: Flow diagram of Scheme 2.

TABLE 6: Setting of parameters in Scheme 2.

\begin{tabular}{|c|c|c|c|c|}
\hline Country A & $\begin{array}{c}\text { Distance between } \\
\text { OA and PPA } \alpha\end{array}$ & $\begin{array}{l}\text { Processing time in } \\
\text { PPA } \alpha\end{array}$ & $\begin{array}{c}\text { Distance between } \\
\text { PPA } \alpha \text { and PA }\end{array}$ & $\begin{array}{c}\text { Distance between } \\
\text { PA and DCA }\end{array}$ \\
\hline & 1 day & 5 days & 4 days & 2 days \\
\hline \multirow[t]{2}{*}{ Country B } & $\begin{array}{l}\text { Distance between } \\
\mathrm{OB} \text { and } \mathrm{PB}\end{array}$ & $\begin{array}{c}\text { Distance between } \\
\text { PB and DCB }\end{array}$ & & \\
\hline & 4 days & 2 days & & \\
\hline \multirow[t]{4}{*}{ Country C } & $\begin{array}{c}\text { Distance between } \\
\text { PC and APC }\end{array}$ & $\begin{array}{c}\text { Distance between } \\
\text { PC and PPC } \beta\end{array}$ & $\begin{array}{c}\text { Processing time in } \\
\text { PPC } \beta\end{array}$ & $\begin{array}{c}\text { Distance between } \\
\text { PPC } \beta \text { and APC }\end{array}$ \\
\hline & 1 day & 2 days & 3 days & 1 day \\
\hline & $\begin{array}{l}\text { Assembling time in } \\
\text { APC }\end{array}$ & $\begin{array}{c}\text { Distance between } \\
\text { DCC and APC }\end{array}$ & & \\
\hline & 2 days & 2 days & & \\
\hline \multirow[t]{2}{*}{ Country D } & $\begin{array}{l}\text { Distance between } \\
\text { PD and APD }\end{array}$ & $\begin{array}{l}\text { Assembling time in } \\
\text { APD }\end{array}$ & $\begin{array}{l}\text { Distance between } \\
\text { APD and DCD }\end{array}$ & \\
\hline & 2 days & 2 days & 2 days & \\
\hline \multirow[t]{2}{*}{$\begin{array}{l}\text { Distance between } \\
\text { the ports }\end{array}$} & $\begin{array}{c}\text { Distance between } \\
\text { PA and PC }\end{array}$ & $\begin{array}{c}\text { Distance between } \\
\text { PB and PC }\end{array}$ & $\begin{array}{c}\text { Distance between } \\
\text { PA and PD }\end{array}$ & $\begin{array}{c}\text { Distance between } \\
\text { PC and PD }\end{array}$ \\
\hline & 15 days & 18 days & 20 days & 23 days \\
\hline
\end{tabular}

In the third possibility of supply chain reconstruction, this paper sets up two processing sites of $\alpha$. One is located in $\mathrm{C}$, called PPC $\alpha$. The other is located in $\mathrm{D}$, called PPD $\alpha$. The processing sites of $\beta$ are the same as Scheme 3, which are called PPC $\beta$ and $\operatorname{PPD} \beta$. PPC $\alpha$ and PPC $\beta$ produce $\gamma$ and $\delta$, respectively, to assemble $\varepsilon$. $\varepsilon$ assembled in $\mathrm{C}$ is for $\mathrm{A}, \mathrm{B}$, and C. $\operatorname{PPD} \alpha$ and $\operatorname{PPD} \beta$ produce $\gamma$ and $\delta$ to assemble $\varepsilon$ for $\mathrm{D}$ only.
Based on the above discussion and assumption, the supply chain model is changed from Figure 3 to Figure 4, which is called Scheme 4.

Setting that the production parameters of $\alpha$ are the same in $\mathrm{C}$ and $\mathrm{D}$, the model parameters of Scheme 4 are shown in Table 12.

According to the settings in Table 12, the model runs the simulation of the international supply chain in 90 days. Then 
TABLE 7: Simulation results of freight volume and period in Scheme 2.

\begin{tabular}{lccr}
\hline Country A & Land freight in A & Port throughput in A & Starting sales time of $\varepsilon$ in A \\
\hline Country B & 18900 tons & 18000 tons & The 59th day \\
\hline & Land freight in B & Port throughput in B & Starting sales time of $\varepsilon$ in B \\
\hline Country C & 37600 tons & 35650 tons & The 61st day \\
\hline Land freight in C & Port throughput in C & Starting sales time of $\varepsilon$ in C \\
\hline Country D & 56860 tons & 46100 tons & The 40th day \\
\hline & Land freight in D & Port throughput in D & Starting sales time of $\varepsilon$ in D \\
\hline
\end{tabular}

TABLE 8: Simulation results of freight cost in Scheme 3.

\begin{tabular}{lcccc}
\hline The cost of land & In the territory of $A$ & In the territory of B & In the territory of C & In the territory of D \\
\hline The cost of ocean & USD 128700 & USD 132000 & USD 362160 & USD 169200 \\
\hline \multicolumn{1}{l}{ A-C } & B-C & A-D & C-D \\
\hline USD 36120 & USD 984140 & USD 78200 & USD 38880 & USD 38880 \\
\hline
\end{tabular}

TABLE 9: Setting of parameters in Scheme 3.

\begin{tabular}{|c|c|c|c|c|}
\hline Country A & $\begin{array}{c}\text { Distance between } \\
\text { OA and PPA } \alpha\end{array}$ & $\begin{array}{c}\text { Processing time in } \\
\text { PPA } \alpha\end{array}$ & $\begin{array}{c}\text { Distance between } \\
\text { PPA } \alpha \text { and PA }\end{array}$ & $\begin{array}{c}\text { Distance between } \\
\text { PA and DCA }\end{array}$ \\
\hline & 1 day & 5 days & 4 days & 2 days \\
\hline \multirow[t]{2}{*}{ Country B } & $\begin{array}{c}\text { Distance between } \\
\mathrm{OB} \text { and } \mathrm{PB}\end{array}$ & $\begin{array}{l}\text { Distance between } \\
\text { PB and DCB }\end{array}$ & & \\
\hline & 4 days & 2 days & & \\
\hline \multirow[t]{4}{*}{ Country C } & $\begin{array}{c}\text { Distance between } \\
\text { PC and PPC } \beta\end{array}$ & $\begin{array}{c}\text { Processing time in } \\
\text { PPC } \beta\end{array}$ & $\begin{array}{c}\text { Distance between } \\
\text { PPC } \beta \text { and APC }\end{array}$ & \\
\hline & 2 days & 3 days & 1 day & \\
\hline & $\begin{array}{c}\text { Distance between } \\
\text { PC and APC }\end{array}$ & $\begin{array}{l}\text { Assembling time in } \\
\text { APC }\end{array}$ & $\begin{array}{c}\text { Distance between } \\
\text { DCC and APC }\end{array}$ & \\
\hline & 1 day & 2 days & 2 days & \\
\hline \multirow[t]{4}{*}{ Country D } & $\begin{array}{c}\text { Distance between } \\
\text { PD and } \operatorname{PPD} \beta\end{array}$ & $\begin{array}{c}\text { Processing time in } \\
\operatorname{PPD} \beta\end{array}$ & $\begin{array}{l}\text { Distance between } \\
\operatorname{PPD} \beta \text { and APD }\end{array}$ & \\
\hline & 1 day & 3 days & 1 day & \\
\hline & $\begin{array}{l}\text { Distance between } \\
\text { PD and APD }\end{array}$ & $\begin{array}{c}\text { Assembling time in } \\
\text { APD }\end{array}$ & $\begin{array}{l}\text { Distance between } \\
\text { APD and DCD }\end{array}$ & \\
\hline & 2 days & 2 days & 2 days & \\
\hline \multirow[t]{2}{*}{$\begin{array}{l}\text { Distance between } \\
\text { the ports }\end{array}$} & $\begin{array}{c}\text { Distance between } \\
\text { PA and PC }\end{array}$ & $\begin{array}{c}\text { Distance between } \\
\text { PB and PC }\end{array}$ & $\begin{array}{c}\text { Distance between } \\
\text { PA and PD }\end{array}$ & $\begin{array}{c}\text { Distance between } \\
\text { PB and PD }\end{array}$ \\
\hline & 15 days & 18 days & 20 days & 35 days \\
\hline
\end{tabular}

TABLE 10: Simulation results of freight volume and period in Scheme 3.

\begin{tabular}{lccc}
\hline Country A & Land freight in A & Port throughput in A & Starting sales time of $\varepsilon$ in A \\
\hline Country B & 18900 tons & 18000 tons & The 59th day \\
\hline Land freight in B & Port throughput in B & Starting sales time of $\varepsilon$ in B \\
\hline Country C & 37600 tons & 36850 tons & The 61st day \\
\hline Country D & Land freight in C & Port throughput in C & Starting sales time of $\varepsilon$ in C \\
\hline & Land freight in D & 20780 tons & The 40th day \\
\hline
\end{tabular}




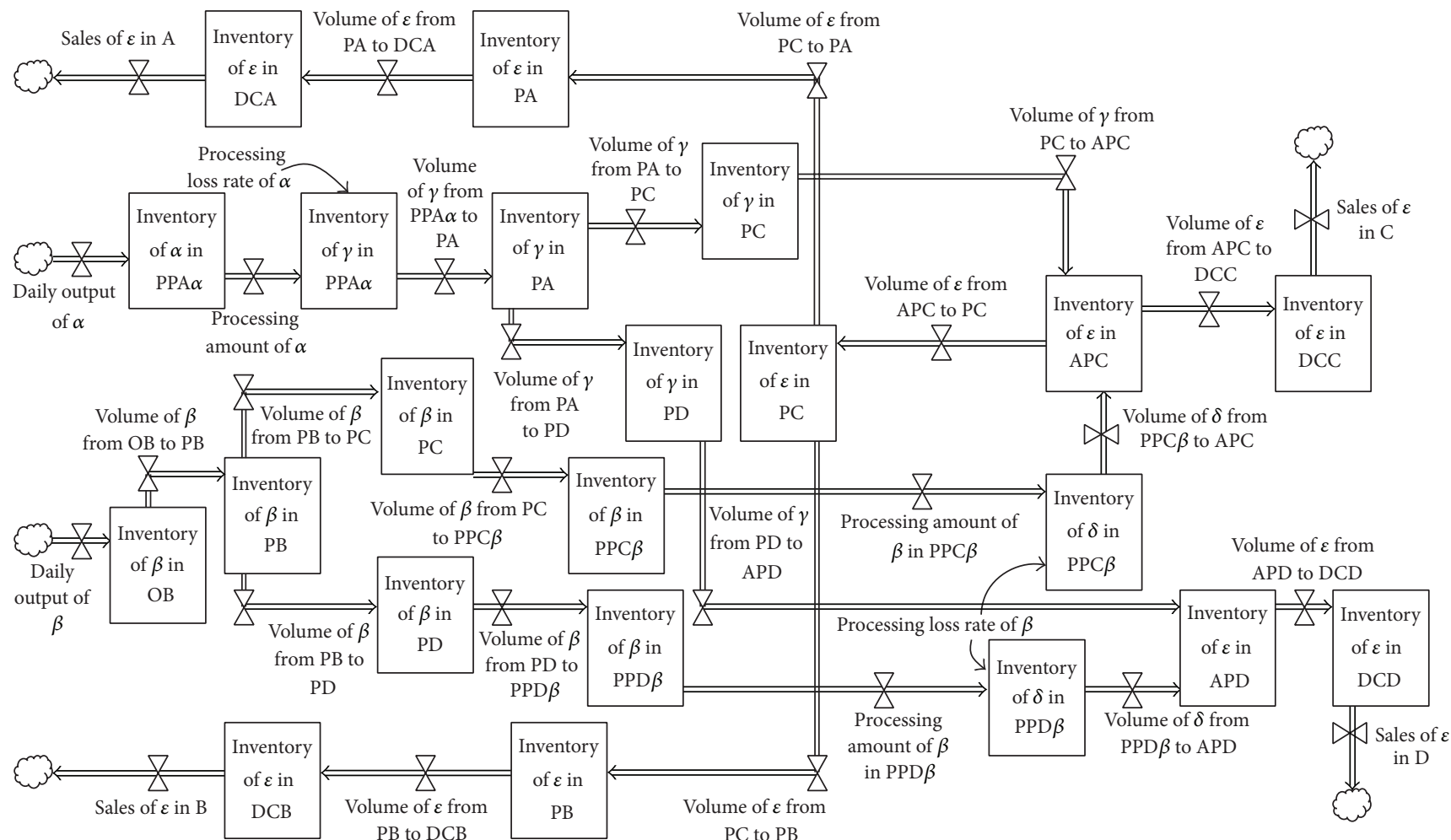

FIgURE 3: Flow diagram of Scheme 3.

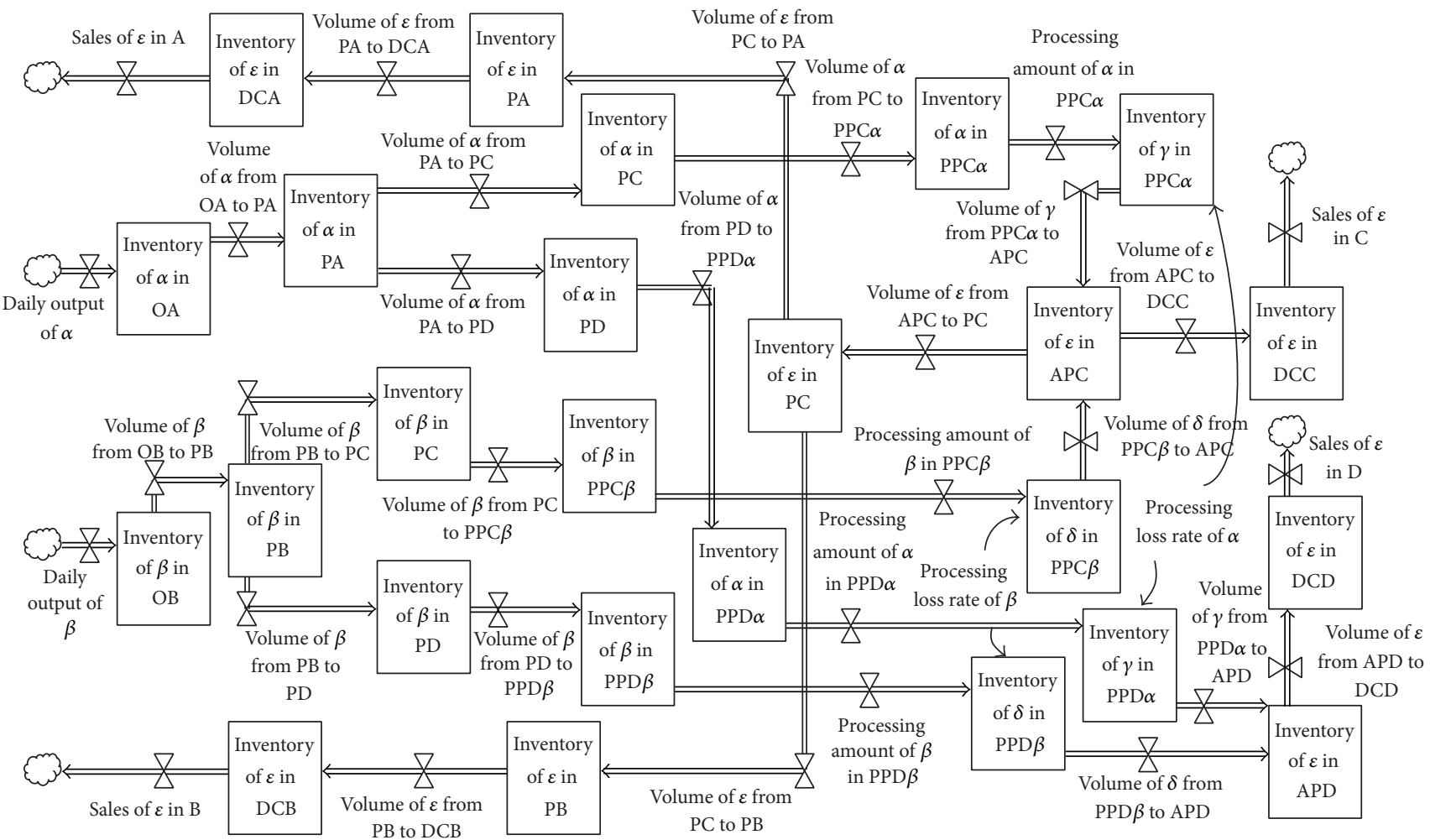

Figure 4: Flow diagram of Scheme 4. 
TABLE 11: Simulation results of freight cost in Scheme 3.

\begin{tabular}{lcccc}
\hline The cost of land & In the territory of A & In the territory of B & In the territory of C & In the territory of D \\
\hline The cost of ocean & USD 128700 & USD 132000 & USD 255960 & USD 299700 \\
\hline \multicolumn{1}{l}{ Total } & USD 36120 & A-D & B-C & B-D \\
\hline USD 971960 & USD 38880 & USD 37400 & USD 43200 \\
\hline
\end{tabular}

TABLE 12: Setting of parameters in Scheme 4.

\begin{tabular}{|c|c|c|c|c|}
\hline Country A & $\begin{array}{c}\text { Distance between } \\
\text { OA and PA }\end{array}$ & $\begin{array}{c}\text { Distance between } \\
\text { PA and DCA }\end{array}$ & & \\
\hline & 4 days & 2 days & & \\
\hline \multirow[t]{2}{*}{ Country B } & $\begin{array}{c}\text { Distance between } \\
\mathrm{OB} \text { and } \mathrm{PB}\end{array}$ & $\begin{array}{c}\text { Distance between } \\
\text { PB and DCB }\end{array}$ & & \\
\hline & 4 days & 2 days & & \\
\hline \multirow[t]{6}{*}{ Country C } & $\begin{array}{c}\text { Distance between } \\
\text { PC and PPC } \alpha\end{array}$ & $\begin{array}{c}\text { Distance between } \\
\text { PC and PPC } \beta\end{array}$ & $\begin{array}{l}\text { Distance between } \\
\text { PPC } \alpha \text { and APC }\end{array}$ & $\begin{array}{c}\text { Distance between } \\
\text { PPC } \beta \text { and APC }\end{array}$ \\
\hline & 1 day & 2 days & 1 day & 1 day \\
\hline & $\begin{array}{c}\text { Processing time in } \\
\text { PPC } \alpha\end{array}$ & $\begin{array}{c}\text { Processing time in } \\
\text { PPC } \beta\end{array}$ & $\begin{array}{c}\text { Assembling time in } \\
\text { APC }\end{array}$ & $\begin{array}{c}\text { Distance between } \\
\text { DCC and APC }\end{array}$ \\
\hline & 5 days & 3 days & 2 days & 2 days \\
\hline & $\begin{array}{c}\text { Distance between } \\
\text { PC and APC }\end{array}$ & & & \\
\hline & 1 day & & & \\
\hline \multirow[t]{4}{*}{ Country D } & $\begin{array}{c}\text { Distance between } \\
\text { PD and PPD } \alpha\end{array}$ & $\begin{array}{c}\text { Distance between } \\
\text { PD and PPD } \beta\end{array}$ & $\begin{array}{l}\text { Distance between } \\
\mathrm{PPD} \alpha \text { and APD }\end{array}$ & $\begin{array}{l}\text { Distance between } \\
\operatorname{PPD} \beta \text { and APD }\end{array}$ \\
\hline & 1 day & 1 day & 2 days & 1 day \\
\hline & $\begin{array}{c}\text { Processing time in } \\
\text { PPD } \alpha\end{array}$ & $\begin{array}{c}\text { Processing time in } \\
\text { PPD } \beta\end{array}$ & $\begin{array}{c}\text { Assembling time in } \\
\text { APD }\end{array}$ & $\begin{array}{c}\text { Distance between } \\
\text { DCD and APD }\end{array}$ \\
\hline & 5 days & 3 days & 2 days & 2 days \\
\hline \multirow[t]{2}{*}{$\begin{array}{l}\text { Distance between } \\
\text { the ports }\end{array}$} & $\begin{array}{c}\text { Distance between } \\
\text { PA and PC }\end{array}$ & $\begin{array}{c}\text { Distance between } \\
\text { PB and PC }\end{array}$ & $\begin{array}{c}\text { Distance between } \\
\text { PA and PD }\end{array}$ & $\begin{array}{c}\text { Distance between } \\
\text { PB and PD }\end{array}$ \\
\hline & 15 days & 18 days & 20 days & 35 days \\
\hline
\end{tabular}

TABLE 13: Simulation results of freight volume and period in Scheme 4.

\begin{tabular}{lccc}
\hline Country A & Land freight in A & Port throughput in A & Starting sales time of $\varepsilon$ in A \\
\hline Country B & 37700 tons & 35800 tons & The 59th day \\
\hline Lountry C & Land freight in B & Port throughput in B & Starting sales time of $\varepsilon$ in B \\
\hline Lountry D & Land freight in C & 36850 tons & The 61st day \\
\hline & Land freight in D & Port throughput in C & Starting sales time of $\varepsilon$ in C \\
\hline
\end{tabular}

classifying the statistics according to different countries, the results are shown in Table 13.

The setting of freight rates of Scheme 4 is the same as Scheme 1. After calculation, the results of transportation cost are shown in Table 14.

\section{The Analysis of Simulation}

4.1. The Comparisons of the Freight Volume Changes in the Four Schemes. According to the data from the model simulation, a chart of volume comparison is made as Figures 5-8. 
TABLE 14: Simulation results of freight cost in Scheme 4.

\begin{tabular}{lcccc}
\hline The cost of land & In the territory of A & In the territory of B & In the territory of C & In the territory of D \\
\hline The cost of ocean & USD 133500 & USD 132000 & USD 287640 & USD 345780 \\
\hline \multicolumn{1}{l}{ Total } & USD 37400 & B-C & A-D & B-D \\
\hline
\end{tabular}

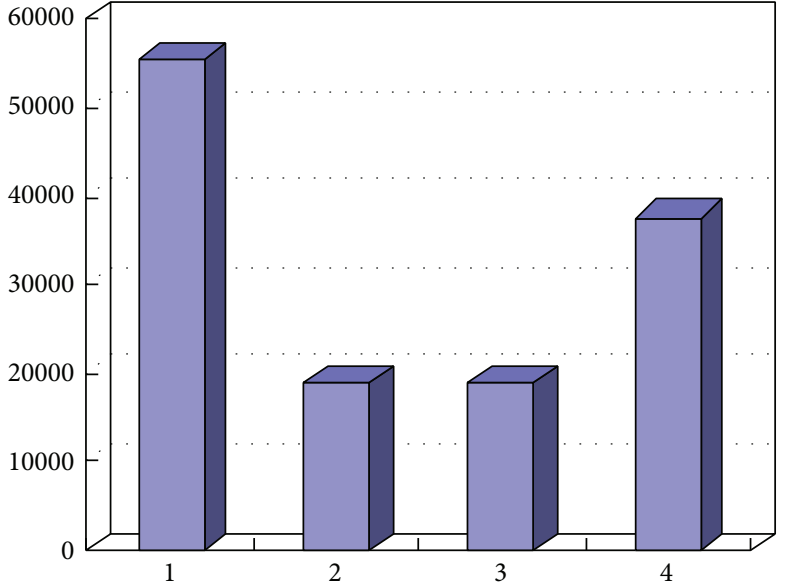

Land freight in A

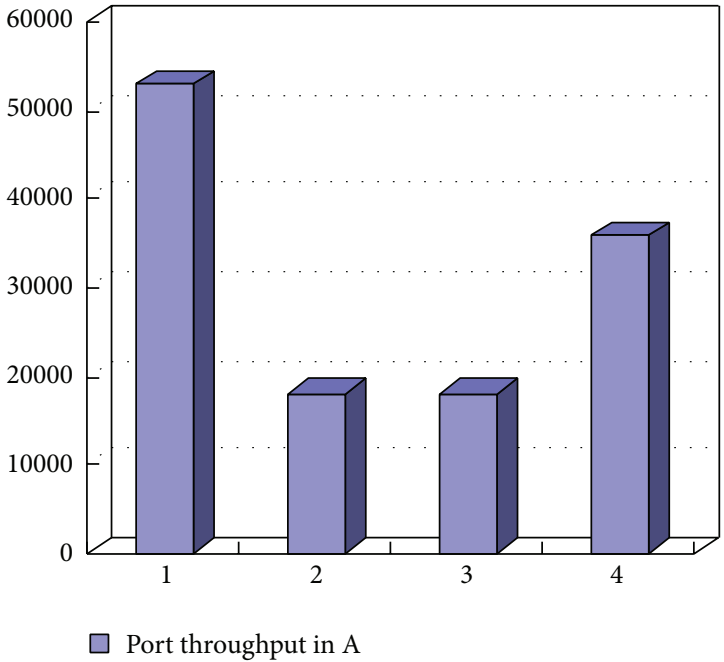

FIGURE 5: Freight volume of A in different schemes.

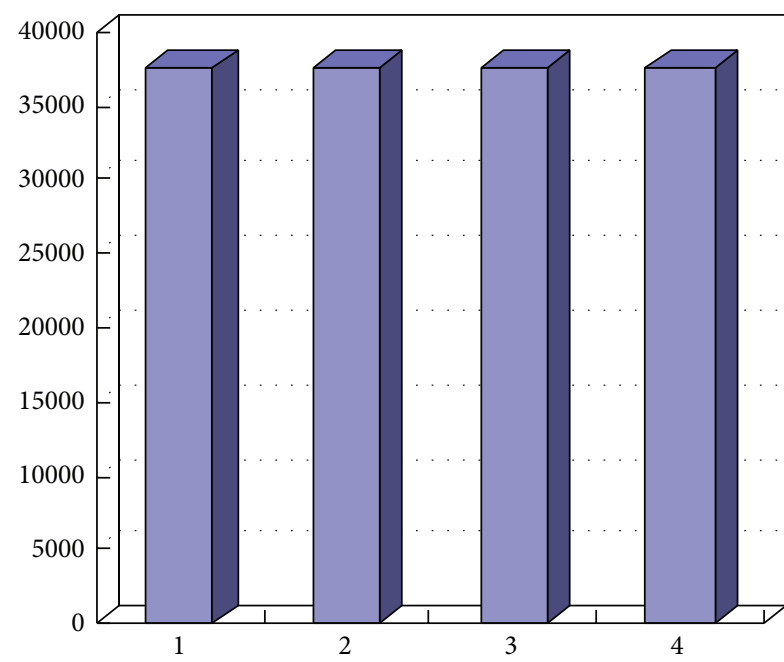

$\square$ Land freight in B

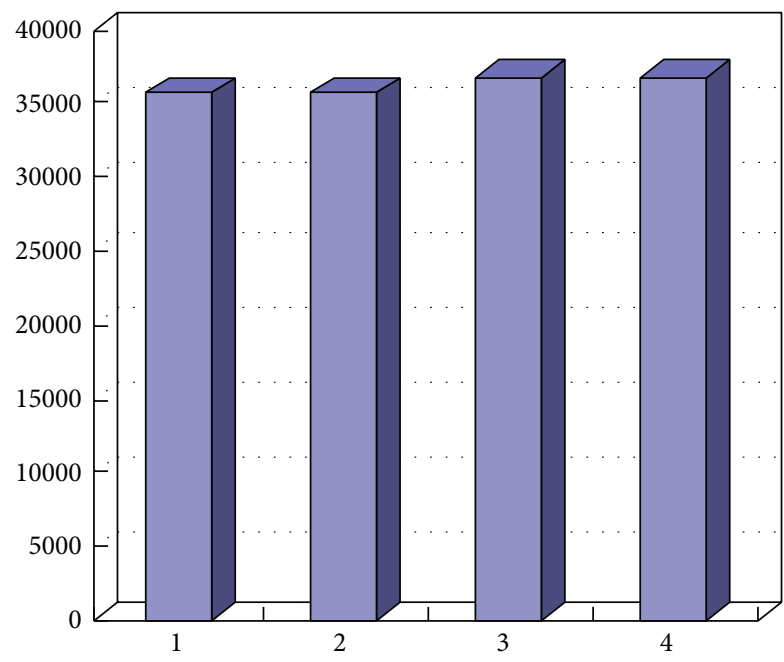

$\square$ Port throughput in B

Figure 6: Freight volume of B in different schemes.

In the model setting, country A plays the role as a raw material supplier. But this country's demand of manufactured goods is low, just like some other countries in the real world. The logistics business of $A$ in the chain consists of $\alpha$ exported and $\varepsilon$ imported, average 600 and 50 tons/day, respectively. The former is more. So before the $3 \mathrm{D}$ printing application, the infrastructures and machineries in A are mainly designed for the bulk transportation of $\alpha$. After the new technology application, there are three schemes. According to Figure 5, in Schemes 2 and 3 the processing plant of printing material is set near the origin. The main transport object is changed from $\alpha$ to $\gamma$, and the volume is reduced to $1 / 3$ of the primary chain. The total freight in this territory has greatly decreased. In Scheme 4, the processing plant is set back in C and D, 


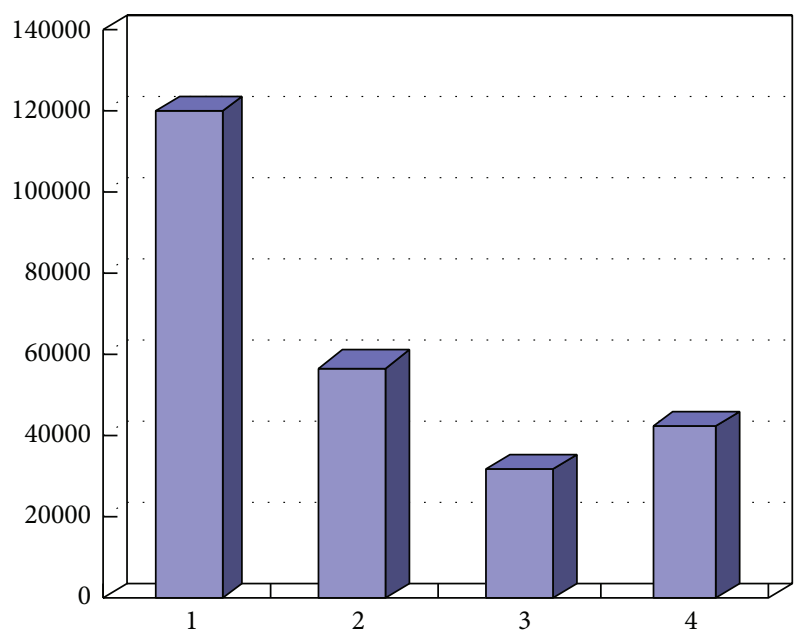

$\square$ Land freight in C

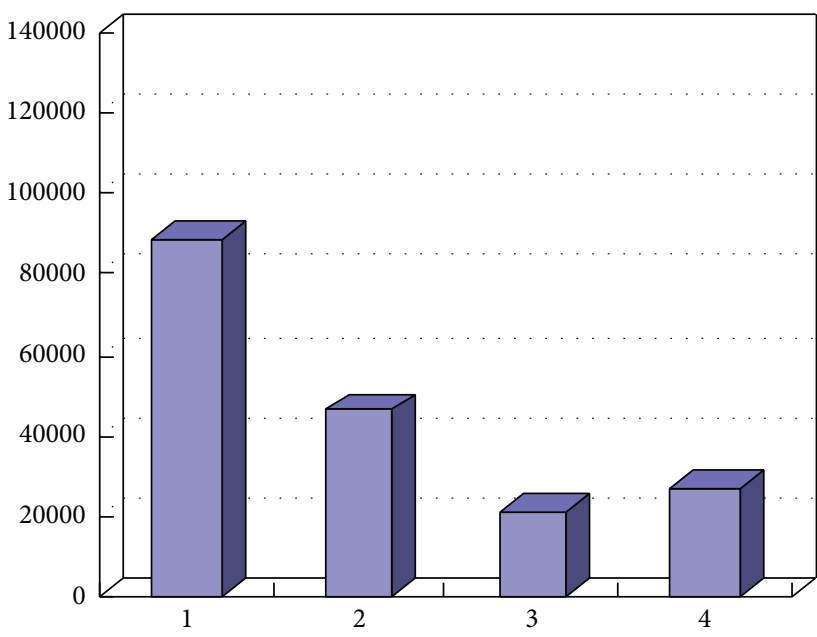

$\square$ Port throughput in $\mathrm{C}$

Figure 7: Freight volume of $\mathrm{C}$ in different schemes.
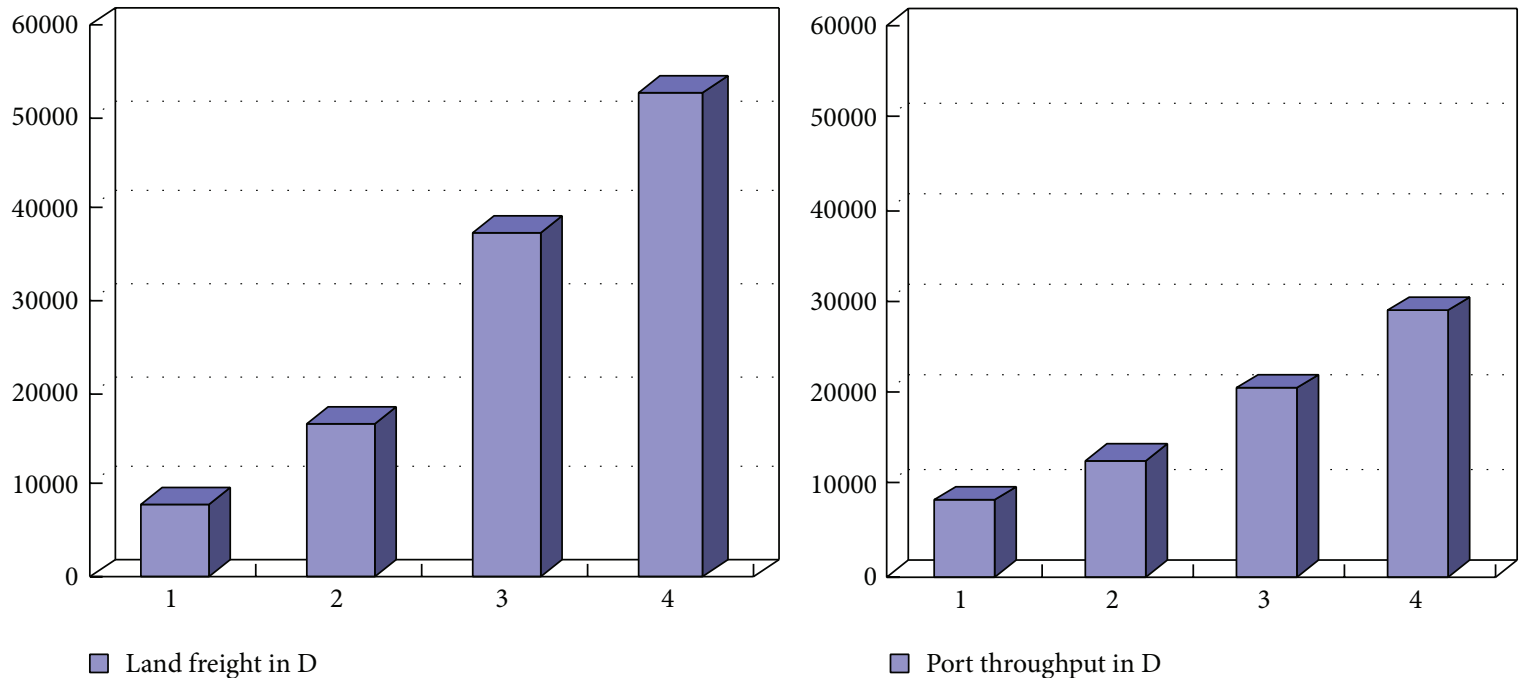

FIgURE 8: Freight volume of D in different schemes.

not in A. And the processing loss rate of $\alpha$ declines. That would still reduce its demand. So the total freight volume of Scheme 4 is less than that of Scheme 1 and more than that of Schemes 2 and 3. In the aspect of the port throughput, the major transport routes in A are "origin/processing plant $\rightarrow$ port" and "port $\rightarrow$ distribution center," so the data of port throughput and the land freight in the territory are not too dissimilar.

In the model setting, country B plays the role as a raw material supplier and its supply is not affected by the new technology. And this country has low demand of manufactured goods. As shown in Figure 6, the total freight volumes in the four schemes are nearly the same. It means that the production of $\beta$ and the sales of $\varepsilon$ are relatively fixed, because the $3 \mathrm{D}$ printing application is not closely related to the material flows in $\mathrm{B}$.

In the model setting, country $\mathrm{C}$ plays the role as a global manufacturing center. The $3 \mathrm{D}$ printing application has brought great change to the logistics situation in C. According to Figure 7, in Scheme 1 the domestic land freight volume and port throughput in $\mathrm{C}$ are very large. The former is more. This is because the main manufacturing process of $\varepsilon$ is put here. The internal and international material flows of raw, semi, and finished products are very frequent, especially in land compared to in port. But after $3 \mathrm{D}$ printing application, quite a part of $\varepsilon$ is directly produced and sold in $\mathrm{D}$. That has reduced the manufacturing and logistics activities in $\mathrm{C}$ significantly. In Scheme 2, the processing of $\beta$ remaining in $C$ makes its 


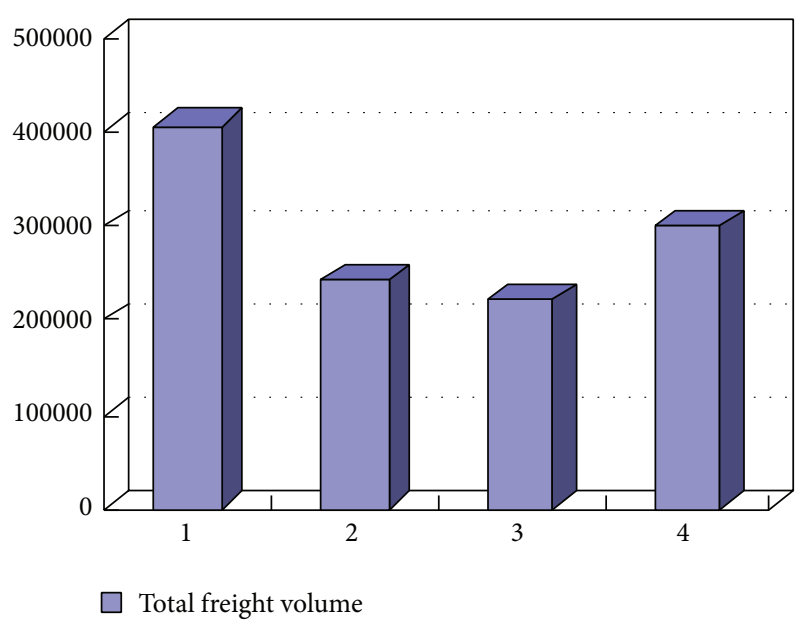

FIGURE 9: Total freight volume in different schemes.

logistics activities not decline so fast. When in Schemes 3 and 4 , a part of the $\beta$ processing transferred to $\mathrm{D}$ has far more reduced the freight in $\mathrm{C}$. It can be expected that the logistic activities in $\mathrm{C}$ will be reduced more if $\varepsilon$ produced for $\mathrm{A}$ and $\mathrm{B}$ also return to their local production.

In the model setting, country D plays the role as the main market of finished product. The largest demand site of $\mathcal{E}$, such as $\mathrm{D}$, should be the best place for its manufacturing activities theoretically. However, due to the international industrial division of labor in recent decades, the production sites have tended to cluster in the country C. So the logistics activities in $\mathrm{D}$ are not large. As 3D printing technology changes the existing mode of manufacturing, the production site of the final product has been shifting to the end of chain. D country's logistics business is rising. According to Figure 8, with the processing and manufacturing activities continuing to flow from $\mathrm{C}$ to $\mathrm{D}$, the freight volume in $\mathrm{D}$ has increased significantly from Scheme 2 to Scheme 4. In Scheme 2, the volume of D is lower than that of C. In Schemes 3 and 4, the volume of $\mathrm{D}$ has already been more than that of $\mathrm{C}$. This shows that the $3 \mathrm{D}$ printing technology will change not only the supply chain mode, but also the logistics situation of the relevant areas. But the port throughput growth rate is much less than that of the land freight. Because D's manufacturing activities are mainly for domestic consumers. That is different from $\mathrm{C}$, in which the products are sold to both local and foreign market.

In addition to the comparisons of the same country in different schemes, the comparisons of the four schemes' total freight volumes are necessary. Adding up the land and sea data of different schemes, the results are shown in Figure 9.

As shown in Figure 9, before 3D printing application the total freight volume of Scheme 1 is the highest. After this technology optimizing the whole international supply chain, the volumes have different degrees of decline in Schemes 2, 3 , and 4 , due to the reduction of processing loss. Among them, the amount of Scheme 3 is the lowest. In this scheme $\alpha$ is processed into $\gamma$ locally and then exported. It can better improve the efficiency of the supply chain.

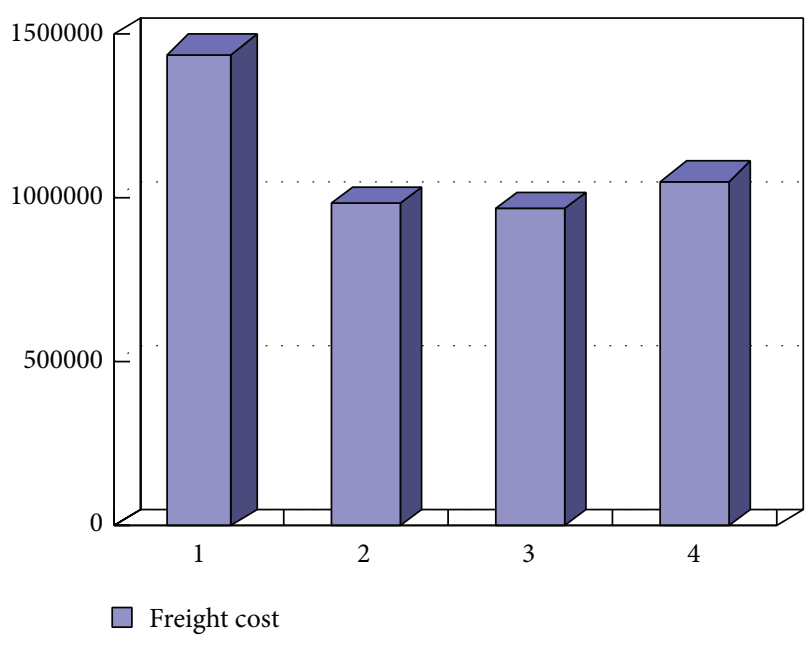

FIgURE 10: Total freight cost in different schemes.

TABLE 15: Starting sales times of the finished product in different schemes.

\begin{tabular}{lcccc}
\hline & Scheme 1 & Scheme 2 & Scheme 3 & Scheme 4 \\
\hline $\begin{array}{l}\text { Starting sales time of } \\
\varepsilon \text { in A }\end{array}$ & 59 & 59 & 59 & 59 \\
$\begin{array}{l}\text { Starting sales time of } \\
\varepsilon \text { in B }\end{array}$ & 62 & 61 & 61 & 61 \\
$\begin{array}{l}\text { Starting sales time of } \\
\varepsilon \text { in C }\end{array}$ & 40 & 40 & 40 & 40 \\
$\begin{array}{l}\text { Starting sales time of } \\
\varepsilon \text { in D }\end{array}$ & 67 & 68 & 52 & 52 \\
\hline
\end{tabular}

4.2. The Comparisons of the Freight Cost Changes in the Four Schemes. According to the data from the model simulation, a chart of volume comparison is made as Figure 10.

Different transportation routes and package form will result in different freight cost. Compare Figure 9 to Figure 10, the range decline of cost is less than that of volume. The total volume reduced, but the cheaper logistics selection in Scheme 1 , bulk for $\alpha$, has changed to the more expensive one in other schemes, container for $\gamma$. The container cost's increase offsets the volume's decline. So Schemes 2, 3, and 4 have almost the same cost. That is not the same as the volume. But among them the lowest is still Scheme 3 .

4.3. The Comparisons of the Freight Cost Changes in the Four Schemes. To evaluate the supply chain reconstruction, in addition to the volume and cost, the length of the chain is important. The shorter the chain, the quicker the response of the production. When the finished products are sent to the distribution center, they are prepared to be sold. Here we set the distribution center as the end of the supply chain. According to the simulation, if starting the production of raw materials in the first day, the earliest days to reach the distribution centers in the four schemes are shown in Table 15.

According to Table 15, in the four schemes the products $\mathcal{E}$ sold in $\mathrm{A}, \mathrm{B}$, and $\mathrm{C}$ are manufactured in $\mathrm{C}$, so their starting sales time has not changed. But for $\varepsilon$ in $\mathrm{D}$, when comparing 
Schemes 2, 3, and 4, the starting sales time is different. In Scheme 2 it starts sales on the 68th day. In Schemes 3 and 4 , it starts sales on the 52 nd day, because in Scheme 2 , the manufacturing of $\varepsilon$ has to wait for the semiproduct from overseas. In Schemes 3 and 4, besides $\varepsilon$, the processing of $\alpha$ and $\beta$ is also shifting to $\mathrm{D}$. This shows that only the manufacturing location of the finished product changing cannot completely affect the supply chain length. The chain length will be significantly shortened only after the matching production system is transferred along with the final product.

\section{Conclusions and Recommendations for Future Investigations}

According to the simulation results, when the $3 \mathrm{D}$ printing application matures, the future of the global industrial structure is bound to have a major change. The final manufacturing sites will shift to the end of supply chain. At the same time, the chain's total freight volume and cost will be greatly reduced. These will lead to the innovation of the existing logistics mode in relevant countries. Therefore, how should the policy makers be prepared to deal with this new technology?

The reconstruction of international supply chain has many possibilities. In addition to the above schemes, also there may be other options, such as that $\mathrm{D}$ but not $\mathrm{C}$ becomes the finished product's manufacturer for $\mathrm{A}$ and $\mathrm{B}$ or that $\mathrm{A}$ and $\mathrm{B}$ produce and market all by themselves, and so forth. But in accordance with the current international industrial layout, in the short term Schemes 2, 3, and 4 are more likely to occur. In these schemes, the freight volume and cost of Scheme 3 are the lowest, and its chain length is the shortest, which can quickly and cheaply respond to the consumers' demand. If reconstructing the supply chain in accordance with this scheme, the raw material $\alpha$ is processed to the printing material in $\mathrm{A}$ and then shipped to $\mathrm{C}$ and $\mathrm{D}$. The other raw material $\beta$ is transported to $C$ and $D$ and then processed. Also the final assembly process occurs in $C$ and D. Under this scheme trend, the relevant policy makers should have the following measures.

5.1. For Country A. According to the simulation, due to the transports mode changed from bulk for $\alpha$ to container for $\gamma$, country A should reform its logistics facilities, such as conveyance and infrastructure, to adapt to $3 \mathrm{D}$ printing materials circulation. Moreover, the main logistics route in the supply chain is from origin to processing plant and then to port. Therefore, the policy makers should encourage relevant enterprises to advance the layout, to strengthen the construction of the route according to appropriate standards.

In addition to the hardware reform, the new logistics business mode should be developed. In Scheme $1, \alpha$ is exported in bulk, and $\varepsilon$ is imported in container. They use different means of transport. The vehicles are not the same. One vehicle loads the bulk cargo $\alpha$ to the next station but returns in empty and could not load the cargo $\varepsilon$. This kind of vehicle is not fit for the container cargo. The cargo $\varepsilon$ has to choose other kinds of vehicle. This unbalanced transport demand is not good to improve the comprehensive load rate and reduce the logistics cost. In Scheme 3, the transport object changes to the container. An efficient logistics system should be established to arrange the container loading $\gamma$ to $\mathrm{C}$ or $\mathrm{D}$ and then loading $\varepsilon$ back to $\mathrm{A}$. One vehicle goes with the container cargo $\gamma$ and returns with the container cargo $\varepsilon$. That would significantly reduce the operation cost of supply chain.

5.2. For Country B. In the setting, $\beta$ from $B$ cannot be processed by the $3 \mathrm{D}$ printing. In the four schemes, this country's logistics situation has only changed a little. But it is still influenced by the new technology. As the previous analysis, if part of the manufacture of $\varepsilon$ is transferred to $\mathrm{D}$, the matched processing of $\beta$ should do the same. That would effectively shorten the length of supply chain. If the processing of $\beta$ is still in $\mathrm{C}$, the chain length remains constant and cannot get optimized. Therefore, as an important factor to affect the supply chain reconstruction, the processing location of $\beta$ will affect B's supply chain partner's selection and the whole chain's efficiency. This needs to be determined by further research on the relationship between $\alpha$ and $\beta$ production.

5.3. For Country C. The influence factors of the supply chain include not only the logistics cost, but also the human resource cost and capital cost, and so forth. In the existing international industrial division, country $\mathrm{C}$ may rely on these advantages to attract foreign investment and become a global manufacturing center. However, the application of 3D printing will have more emphasis on the response of the customer in the chain end. The importance of human resource cost in the chain will be weakened. That would speed up the industry transferred from $\mathrm{C}$ to $\mathrm{D}$. In order to mitigate the negative impact of the new technology, the country $\mathrm{C}$ should carry out the following measures.

Firstly, according to the simulation, the processing of $3 \mathrm{D}$ printing materials plays an important role in the chain reconstruction. Putting its processing site in $\mathrm{A}$ or $\mathrm{D}$, that has different effects to the whole chain. Although Scheme 3 is the optimal choice, it may not be feasible, because country A is likely to be just a relatively backward resource exporting country, which lacks adequate technical talents and funds in the local production of printing materials. Therefore, $\mathrm{C}$ should lead to the establishment of a strategic alliance of supply chain with $\mathrm{A}$ and $\mathrm{C}$, which provides the necessary financial and technical supports to A. It includes the direct founding of a branch or the participation of a local enterprise, to assist $\mathrm{A}$ maintaining the processing of $\alpha$ locally. This is also an important measure to optimize the supply chain.

Secondly, the simulation shows that the demand of the finished products in different counties determines their logistics industry development. The logistics business shrunk in $\mathrm{C}$ due to the outflow of manufacture. Therefore, the policy makers should pay attention to support the industries which will be probably used for the $3 \mathrm{D}$ printing technology. Increasing the domestic consumers' interest and demand for the $3 \mathrm{D}$ printing through various means can promote the local logistics enterprises dedicated to the development of relevant business. Even if its demand is less than D's, it could offset the decline of logistics in $\mathrm{C}$ to a certain degree. Its advantages could be maintained in the supply chain. 
5.4. For Country D. According to the simulation, the freight in $\mathrm{D}$ has different degrees of rise in the above schemes. The application of 3D printing has positive impact on D's logistics industry. For this kind of countries, the policy makers should be prepared for the collaborative research between the $3 \mathrm{D}$ printing industry development and the domestic logistics optimization of hardware and software. Which industries will be more driven by this new technology? Has the local infrastructure limited the development of new industries? Could the existing supply chain mode maximize the advantage of the new technology? Country D should take advantage of the opportunity of manufacturing reflux, to design and improve new logistics mode with 3D printing application.

As $3 \mathrm{D}$ printing technology has not been widely used, the relevant research data is lacking. There are some assumptions in the model. And the research here has just focused on the aspect of logistics. These are the problems of this paper. In the further study, more factors of the international supply chain should be considered, such as the human resource, capital, and technical level in different countries. Then we choose some industries to make key researches, in which the 3D printing application has been mature, to make more accurate industrial prediction and propose reasonable countermeasures.

\section{Competing Interests}

The author declares that there is no conflict of interests regarding the publication of this paper.

\section{Acknowledgments}

This research is supported by Foundation for Distinguished Young Talents in Higher Education of Guangdong, China (2015WQNCX088), and the Guangdong Base for Practicing the Scientific View on Development.

\section{References}

[1] P. Olla, “Opening Pandora's 3D printed box," IEEE Technology and Society Magazine, vol. 34, no. 3, pp. 74-80, 2015.

[2] V. Petrovic, J. Vicente Haro Gonzalez, O. Jordá Ferrando, J. Delgado Gordillo, J. Ramon Blasco Puchades, and L. Portoles Grinan, "Additive layered manufacturing: sectors of industrial application shown through case studies," International Journal of Production Research, vol. 49, no. 4, pp. 1061-1079, 2011.

[3] R. Paul and S. Anand, "Process energy analysis and optimization in selective laser sintering," Journal of Manufacturing Systems, vol. 31, no. 4, pp. 429-437, 2012.

[4] W. Liu, Y. Li, J. Liu, X. Niu, Y. Wang, and D. Li, "Application and performance of 3D printing in nanobiomaterials," Journal of Nanomaterials, vol. 2013, Article ID 681050, 7 pages, 2013.

[5] P. Liu, S. H. Huang, A. Mokasdar, H. Zhou, and L. Hou, “The impact of additive manufacturing in the aircraft spare parts supply chain: supply chain operation reference (scor) model based analysis," Production Planning \& Control, vol. 25, pp. 11691181, 2014.

[6] X. Li, R. Cui, L. Sun et al., "3D-printed biopolymers for tissue engineering application," International Journal of Polymer Science, vol. 2014, Article ID 829145, 13 pages, 2014.
[7] J. Sun, W. Zhou, D. Huang, J. Y. H. Fuh, and G. S. Hong, "An overview of 3D printing technologies for food fabrication," Food and Bioprocess Technology, vol. 8, no. 8, pp. 1605-1615, 2015.

[8] N. J. R. Venekamp and H. T. Le Fever, "Application areas of additive manufacturing: from curiosity to application," IEEE Technology and Society Magazine, vol. 34, no. 3, pp. 81-87, 2015.

[9] F. Cooper, "Sintering and additive manufacturing: the new paradigm for the jewellery manufacturer," Johnson Matthey Technology Review, vol. 59, no. 3, pp. 233-242, 2015.

[10] I. J. Petrick and T. W. Simpson, "Point of view: 3D printing disrupts manufacturing: how economies of one create new rules of competition," Research-Technology Management, vol. 56, no. 6, pp. 12-16, 2013.

[11] M. Zeleny, "High technology and barriers to innovation: from globalization to relocalization," International Journal of Information Technology \& Decision Making, vol. 11, no. 2, pp. 441456, 2012.

[12] S. Mellor, L. Hao, and D. Zhang, "Additive manufacturing: a framework for implementation," International Journal of Production Economics, vol. 149, pp. 194-201, 2014.

[13] T. Kurfess and W. J. Cass, "Rethinking additive manufacturing and intellectual property protection," Research Technology Management, vol. 57, no. 5, pp. 35-42, 2014.

[14] T. Rayna and L. Striukova, "Open innovation 2.0: is co-creation the ultimate challenge?" International Journal of Technology Management, vol. 69, no. 1, pp. 38-53, 2015.

[15] F. Thiesse, M. Wirth, H. Kemper et al., "Economic implication of additive manufacturing and the contribution of MIS," Business \& Information Systems Engineering, vol. 57, no. 2, pp. 139-148, 2015.

[16] C. Weller, R. Kleer, and F. T. Piller, "Economic implications of 3D printing: market structure models in light of additive manufacturing revisited," International Journal of Production Economics, vol. 164, pp. 43-56, 2015.

[17] Z. Zhu, V. G. Dhokia, A. Nassehi, and S. T. Newman, "A review of hybrid manufacturing processes-state of the art and future perspectives," International Journal of Computer Integrated Manufacturing, vol. 26, no. 7, pp. 596-615, 2013.

[18] L. Monostori, P. Valckenaers, A. Dolgui, H. Panetto, M. Brdys, and B. C. Csáji, "Cooperative control in production and logistics," Annual Reviews in Control, vol. 39, pp. 12-29, 2015.

[19] S. H. Khajavi, J. Partanen, and J. Holmström, "Additive manufacturing in the spare parts supply chain," Computers in Industry, vol. 65, no. 1, pp. 50-63, 2014.

[20] S. H. Khajavi, J. Partanen, J. Holmström, and J. Tuomi, "Risk reduction in new product launch: a hybrid approach combining direct digital and tool-based manufacturing," Computers in Industry, vol. 74, pp. 29-42, 2015.

[21] J. Manners-Bell and K. Lyon, "The implications of 3D printing for the global logistics industry," Transportation Intelligence, vol. 8, pp. 1-6, 2012.

[22] Y. Jin, S. Ji, T. Li et al., "The impact and countermeasures of 3D printing on logistics industry," Techno Economics \& Management Research, vol. 8, pp. 105-108, 2014.

[23] J. Dawes, R. Bowerman, and R. Trepleton, "Introduction to the additive manufacturing powder metallurgy supply chain," Johnson Matthey Technology Review, vol. 59, no. 3, pp. 243-256, 2015.

[24] A. Barz, T. Buer, and H.-D. Haasis, "Quantifying the effects of additive manufacturing on supply networks by means of a facility location-allocation model," Computational Logistics Working Paper, University of Bremen, Bremen, Germany, 2015, 
http://www.cl.uni-bremen.de/files/buer/publikationen/Barz

Buer_Haasis_Working\%20Paper_12_2105.pdf.

[25] Z. Zhao, "The transnational supply chain quantity discount contract considering the exchange rate variation and the transportation cost sharing," Chinese Journal of Management, vol. 9, no. 6, pp. 913-919, 2012. 

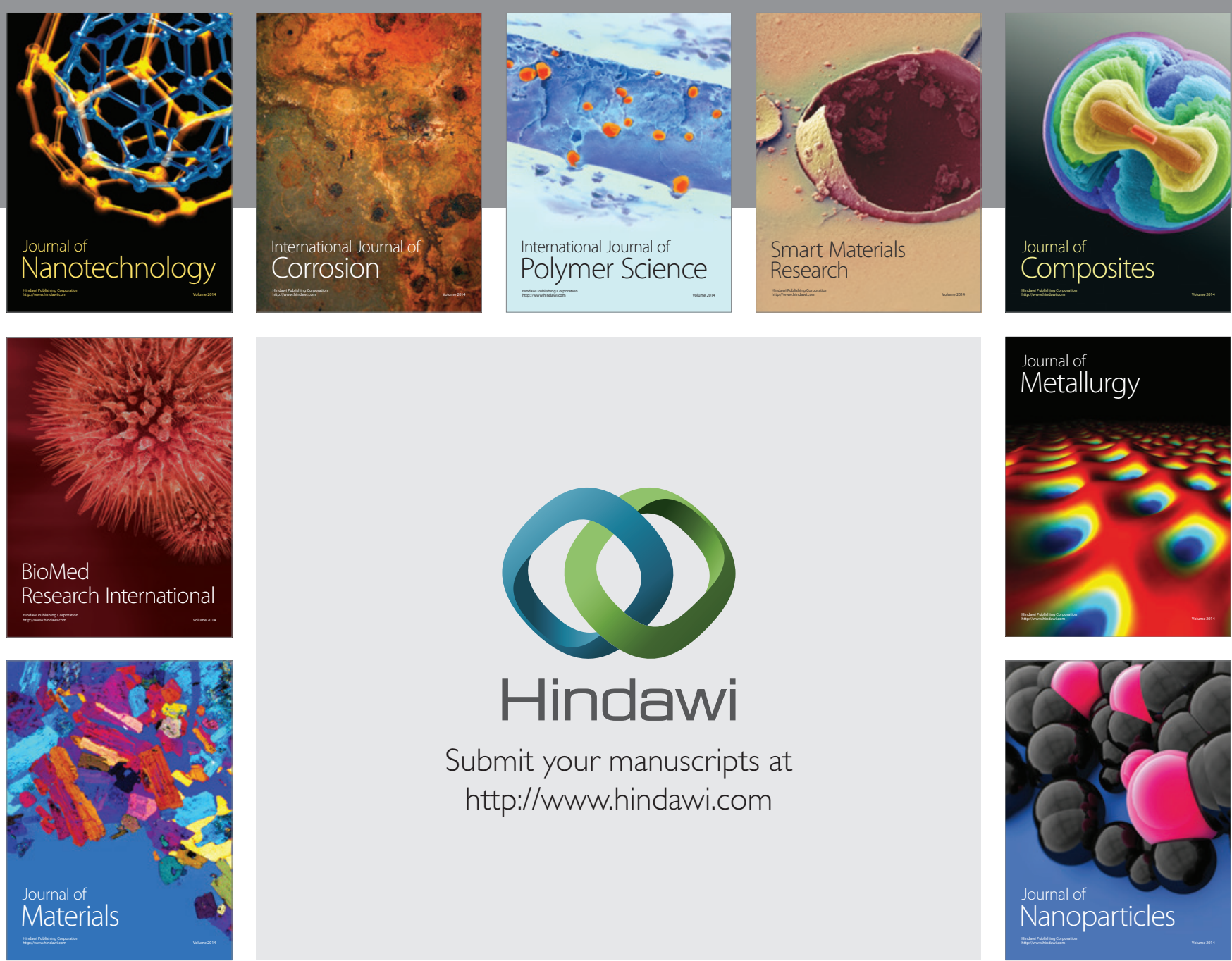

\section{Hindawi}

Submit your manuscripts at

http://www.hindawi.com

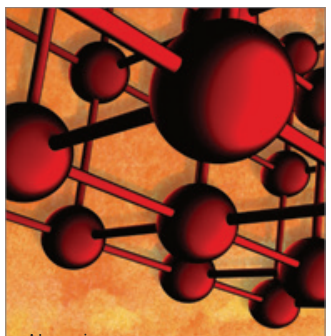

Materials Science and Engineering
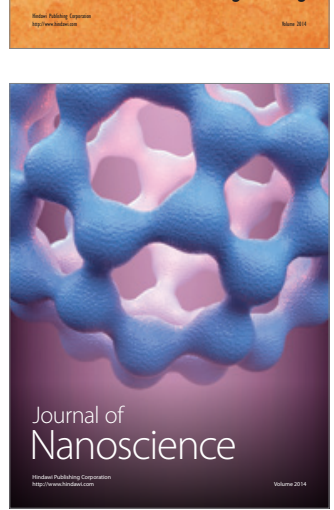
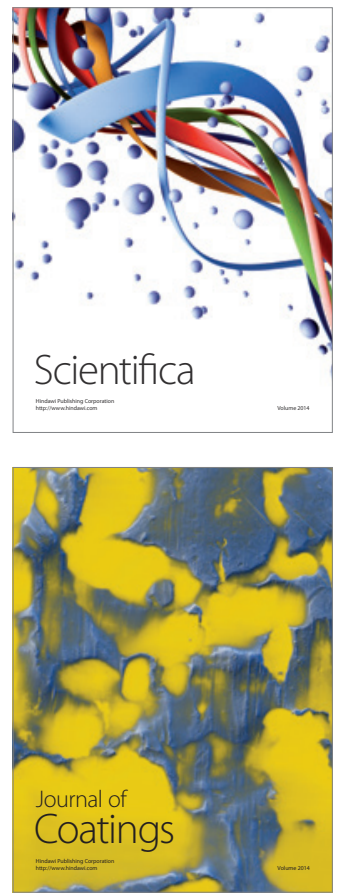
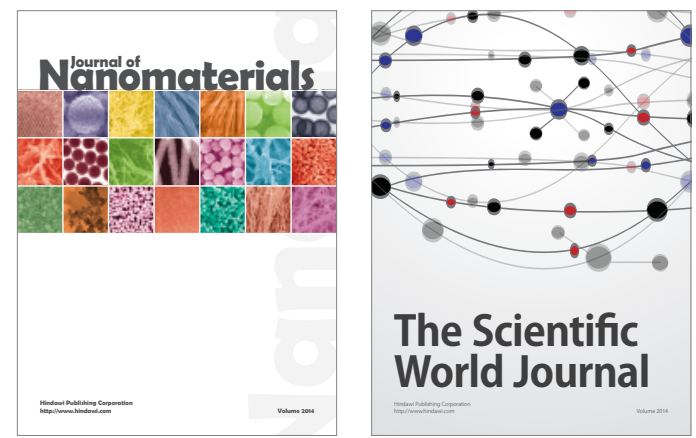

The Scientific World Journal
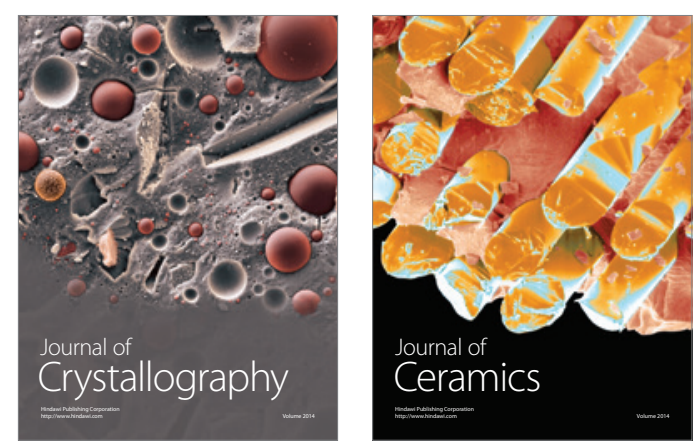
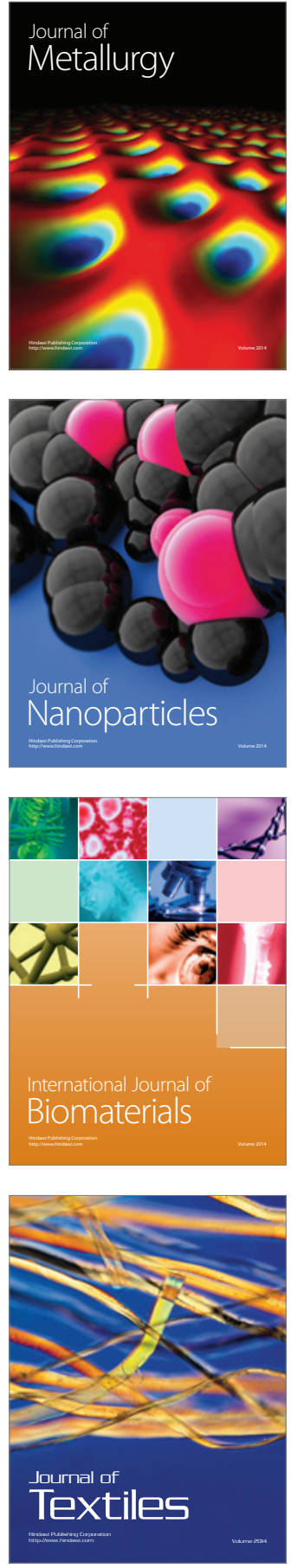